\title{
Phytochemical analysis and Enzyme Inhibition Assay of Aerva javanica for Ulcer
}

\author{
Abdul Wajid Khan ${ }^{1}$, Saleem Jan ${ }^{1}$, Shaista Parveen ${ }^{1}$, Rahmat Ali Khan ${ }^{2 *}$, Asma Saeed ${ }^{3}$, Abdul Jabbar Tanveer ${ }^{4}$ \\ and Anwar Ali Shad ${ }^{5}$
}

\begin{abstract}
Background: Aerva javanica (Burm. f.) Juss. ex Schult. (Amaranthacea) is traditionally used for the treatment of wound healings, cough, diarrhoea, ulcer and hyperglycaemia. The current study was aimed to fractionate and isolate bioactive compounds and ultimately to evaluate their anti-ulcereogenic potential.

Results: In order to achieve these aims, the fractionation, purifications and then biological potential determination of the isolated compounds was carried out. For purification purpose, initially extraction of the plant material was done with aqueous $\mathrm{MeOH}$ in the order of increasing polarity by using solvent-solvent extraction method. Phytochemical analysis revealed the presence of three compounds, 3-hydroxy-4 methoxybenzaldehyde (1), ursolic acid (2) and (E)-N-(4-hydroxy-3-methoxyphenethyl)-3-(4-hydroxy-3-ethoxyphenyl) acryl amide (3). Inhibition of urease activity of various fractions revealed that ethyl acetate fraction showed significant activity $(P<0.05)$ as compared to other fractions. (E)-N-(4-hydroxy-3-methoxyphenethyl)-3-(4-hydroxy-3-ethoxyphenyl) acryl amide (3) showed marked anti ulcer activity $(P<0.05)$.
\end{abstract}

Conclusion: These results suggested the mild potential of $A$. javanica against ulcer.

Keywords: Aerva javanica, Urease activity, Ethyl acetate fraction, Solvent-solvent extraction

\section{Background}

Medicinal plants play important role in the treatment of various disorders [1,2]. The plants of genus Aerva (Amaranthaceae) are perennial herb under shrubs and are found in the North Temperate Zone, especially in the Mediterranean regions and Asia. About 20 species of genus Aerva are present in Pakistan and India; most of them are used in traditional medicinal system [3]. A. javanica (Burm.f.) Juss. ex Schult., locally known as Khar Buta, is found over a broad range of sandy sediments. Various chemical constituents including steroids, triterpenes, lipids, flavonoids, tannins, saponins, alkaloids, sulphates, carbohydrates and glycosides have been isolated from this plant $[4,5]$. The plant has been widely used for its therapeutic effects in relieving the swelling and pain due to

\footnotetext{
* Correspondence: rahmatgul_81@yahoo.com

${ }^{2}$ Department of Biotechnology, University of Science and Technology, Bannu 28100, Pakistan

Full list of author information is available at the end of the article
}

kidney stones [6]. The plant decoction is used for dysentery, gonorrhea and cutaneous infections [7]. A. javanica showed antioxidant [8], antiviral [9], antiplasmodial [10] and antidiabetic activities [11].

Urease (urea amidohydrolase) is an enzyme that catalyzes the hydrolysis of urea to ammonia and carbamate, which is the final step of nitrogen metabolism in living organisms [12]. Carbamate rapidly and spontaneously decomposes, yielding a second molecule of ammonia. These reactions may cause significant increase in $\mathrm{pH}$ and are responsible for negative effects of urease activity in human health and agriculture $[13,14]$. Urease is responsible for urinary tract and gastrointestinal infections, possibly causing severe diseases such as peptic ulcers and stomach cancer as in the case of Helicobacter pylori. Ureases are also involved in the development of urolithiasis, pyelonephritis, hepatic encephalopathy, hepatic coma and urinary catheter encrustation $[15,16]$. Here, we investigated the antiulcer activity of different fractions as well as pure constituents of $A$. javanica. 


\section{Results and discussion}

Compound $\mathbf{1}$ was isolated as white powder from the ethyl acetate fraction by $C C$ and through elution with hexane: EtOAc (5:5). The HR-EIMS of 1 gave the molecular ion peak $(\mathrm{m} / \mathrm{z} 152.0012)$ corresponding to the molecular formula $\mathrm{C}_{8} \mathrm{H}_{8} \mathrm{O}_{3}$ (calcd. for $\mathrm{C}_{8} \mathrm{H}_{8} \mathrm{O}_{3}, 152.0054$ ). The IR spectrum indicated hydroxyl $\left(3600-2500 \mathrm{~cm}^{-1}\right)$, aldehydic $\left(2685 \mathrm{~cm}^{-1}\right)$, carbonyl $\left(1705 \mathrm{~cm}^{-1}\right)$ and aromatic ring $\left(1626 \mathrm{~cm}^{-1}\right)$. An aldehyde was further deduced through EIMS $\left(\mathrm{m} / z\right.$ 151, $\left.\mathrm{M}^{+}-1,100 \%\right)$. The ${ }^{1}$ HNMR spectrum of 1 (Figure 1 \& Table 1 ) showed aldehyde $\left(\delta_{\mathrm{H}}\right.$ 9.82), three aromatic protons $(\delta 7.34 \mathrm{dd}$, $7.43 \mathrm{~d}$ and $7.1 \mathrm{~d})$, hydroxyl $\mathrm{X}\left(\delta_{\mathrm{H}} 8.12\right)$ and a methoxy $\left(\delta_{\mathrm{H}} 3.93, \mathrm{~s}\right)$ functionality. ${ }^{13} \mathrm{C}-\mathrm{NMR}$ signals at $\delta \mathrm{c} 153.8$, $148.0,131.6,125.1,114.5,111.9$ further supported the proposed structure. The signal at $\delta_{C} 56.4$ indicated $-\mathrm{OCH}_{3}$ funtionality. Comparison of spectral data of 1 with literature data identified compound 1 to be 3-hydroxy-4-methoxybenzaldehyde. Ursolic acid (2) (Figure 2 \& Table 2) was obtained as colorless white crystals from the ethyl acetate fraction. IR spectrum showed strong absorptions for hydroxyl $\left(3510 \mathrm{~cm}^{-1}\right)$, carbonyl $\left(1697 \mathrm{~cm}^{-1}\right)$ and double bond (1635 and $815 \mathrm{~cm}^{-1}$ ). The molecular ion peak was at $\mathrm{m} / z 456.3599$ in HR-EI-MS, corresponding to the molecular formula $\mathrm{C}_{30} \mathrm{H}_{48} \mathrm{O}_{3}$ (calcd for, 456.3603). The base peak at $m / z 248$ was due to $\beta$-type triterpenes. The HR-EIMS also exhibited a prominent peak at $\mathrm{m} / z$ 411.3640, due to the loss of $\mathrm{COOH}$ group. The peak at $\mathrm{m} / z 203.1810$ was attributed to the loss of $\mathrm{COOH}$ from fragment at $\mathrm{m} / z 248.1743$ at C-17, representing retero-Diels Alder fragmentation, which is a characteristic of $\Delta 12$ ursane type triterpene. Five tertiary methyl singlets at $\delta_{\mathrm{H}} 1.20,1.11,0.97,0.86$, 0.82 , along with two doublets at $\delta_{\mathrm{H}} 1.06(3 \mathrm{H}, \mathrm{d}$, $J=6.6 \mathrm{~Hz})$ and $\delta_{\mathrm{H}} 0.99(3 \mathrm{H}, \mathrm{d}, J=6.4 \mathrm{~Hz})$ in ${ }^{1} \mathrm{HNMR}$ spectrum were the indication of ursane basic skeleton. The olefinic proton was at $\delta_{\mathrm{H}} 5.20(J=3.5 \mathrm{~Hz})$. A doublet at $2.20 \mathrm{ppm}$ with $J$ value of $11.3 \mathrm{~Hz}$ revealed that the protons at $\mathrm{C}-18$ and $\mathrm{C}-19$ were trans to eachother. Compound 3 (Figure 3 \& Table 3) was obtained as yellowish white amorphous powder from EtOAc fraction. Molecular formula of $\mathbf{3}$ was established as $\mathrm{C}_{19} \mathrm{H}_{21} \mathrm{NO}_{5}$ by HR-EIMS, due to an ion at $\mathrm{m} / z 343.1411$ (calcd 343.1420). The IR absorption bands at $3350 \mathrm{~cm}^{-1}$ and $1650 \mathrm{~cm}^{-1}$ showed hydroxyl and amide functionalities, respectively. Highly conjugated system was exhibited due to strong absorption at 319, 290 and $220 \mathrm{~nm}$ in UV spectrum.

The signals at $\delta_{\mathrm{H}} 6.73(1 \mathrm{H}, \mathrm{d}, J=8.4 \mathrm{~Hz}), \delta_{\mathrm{H}} 6.93$ $(1 \mathrm{H}, \mathrm{dd}, J=\mathrm{s} 8.4,2.0 \mathrm{~Hz})$ and $7.36(1 \mathrm{H}, \mathrm{d}, J=2.0 \mathrm{~Hz})$ were for H-8, H-9 and H-5 of ferulic acid moiety, respectively. The $\mathrm{C}-3$ olefinic proton of the ferulic acid moiety exhibited a doublet at $\delta_{\mathrm{H}} 6.61(J=12.8 \mathrm{~Hz})$ which showed the trans-coupling with $\mathrm{C}-2$ olefinic proton, having a doublet at $\delta_{\mathrm{H}} 5.82(J=12.8 \mathrm{~Hz})$. A further $\mathrm{ABX}$ was observed at $\delta_{\mathrm{H}} 6.67(1 \mathrm{H}, \mathrm{dd}, J=8.0 .2 .0 \mathrm{~Hz})$ for $\mathrm{H}-8^{\prime}, \delta_{\mathrm{H}}$ $6.63(1 \mathrm{H}, \mathrm{d}, J=8.0 \mathrm{~Hz})$ for $\mathrm{H}-7^{\prime}$ and $6.82(1 \mathrm{H}, \mathrm{d}$, $J=2.0 \mathrm{~Hz}$ ) for $\mathrm{H}-4^{\prime}$ in the methoxytyramine moiety. Two coupled triplets of methylene protons at $\delta_{\mathrm{H}} 2.77$ and $\delta_{\mathrm{H}}$ 3.49 (each $2 \mathrm{H}, \mathrm{t}, J=7.2 \mathrm{~Hz}$ ) were assigned to $\mathrm{H}-2^{\prime}$ and $\mathrm{H}-1^{\prime}$, in the methoxtyramine moiety, respectively. In ${ }^{13} \mathrm{C}$-NMR spectrum, the signal at 169.2 indicated an amide functionality. ${ }^{13} \mathrm{C}$-NMR spectrum of compound 3

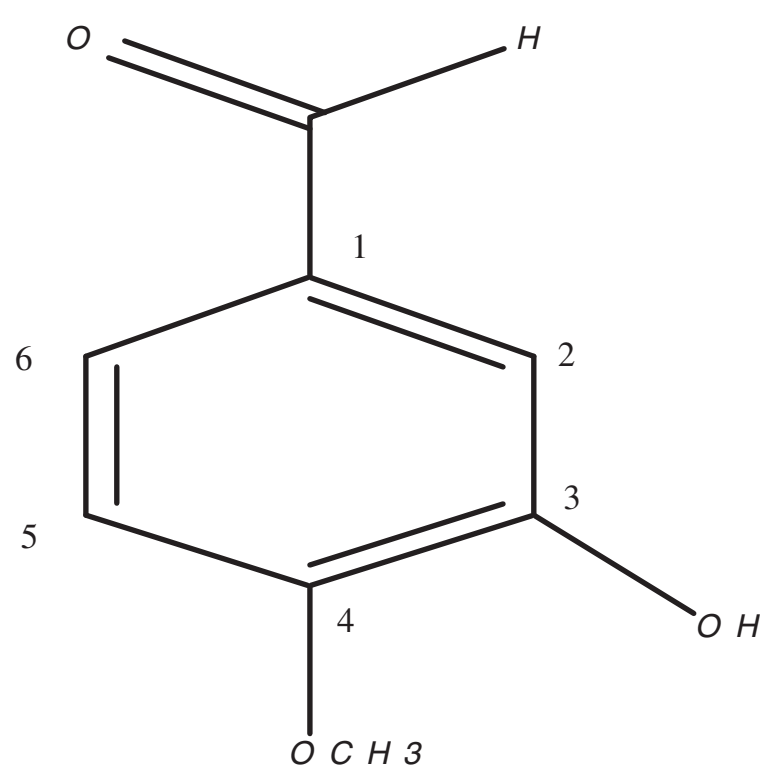

Figure 1 3-hydroxy-4 methoxybenzaldehyde. 
Table $1{ }^{1} \mathrm{H}$ and ${ }^{13} \mathrm{C}$ NMR spectral data for compound 1

\begin{tabular}{llll}
\hline Position & ${ }^{\mathbf{1 3}} \mathbf{C}-\mathrm{NMR}\left(\boldsymbol{\delta}_{\mathrm{C}}\right)$ & ${ }^{\mathbf{1}} \mathbf{H}-\mathrm{NMR}\left(\boldsymbol{\delta}_{\mathrm{H}}\right)$ & $\boldsymbol{J}_{\mathbf{H H}}(\mathbf{H z})$ \\
\hline 1 & 131.6 & - & - \\
2 & 114.5 & 7.43 & $\mathrm{~d}, J=2.0$ \\
3 & 148.0 & - & - \\
4 & 153.8 & - & - \\
5 & 111.9 & 7.12 & $\mathrm{~d}, J=8.7$ \\
6 & 125.1 & 7.34 & $\mathrm{dd}, J=8.7,2.0$ \\
OMe & 56.4 & 3.93 & $\mathrm{~s}$ \\
CHO & - & 9.82 & $\mathrm{~s}$ \\
\hline
\end{tabular}

showed resonances of two methyls; two methylenes, eight methines and seven quaternary carbons. The mass, UV, IR and ${ }^{1} \mathrm{H}$-NMR data proposed compound 3 an amide with phenolic acid funtionality. The position of aromatic substituent was deduced by NOESY experiment. Detailed spectroscopic data established the structure of compound 3 as the (E)-N-(4-hydroxy-3-methoxyphenethyl)-3-(4-hydroxy-3-ethoxyphenyl) acryl amide. Similarly various bioactive compounds were isolated from $A$. javanica [17].

Various fractions of A. javanica were tested preliminary for inhibition of jack bean urease enzyme for their potential against ulcer by using $0.2 \mathrm{mg} / \mathrm{ml}$ of each fraction and thiourea (Table 4). The data of various fractions revealed that ethyl acetate fraction of $A$. javanica exhibited significant inhibition as compared to other fractions. Therefore further chemical investigation was focused on this fraction, which led to the isolation of compounds 1-3.

X3-Hydroxy-4-methoxybenzaldehyde (1), ursolic acid (2), and (E)-N-(4-hydroxy-3-methoxyphenethyl)3-(4-hydroxy-3-ethoxyphenyl) acryl amide (3) were screened

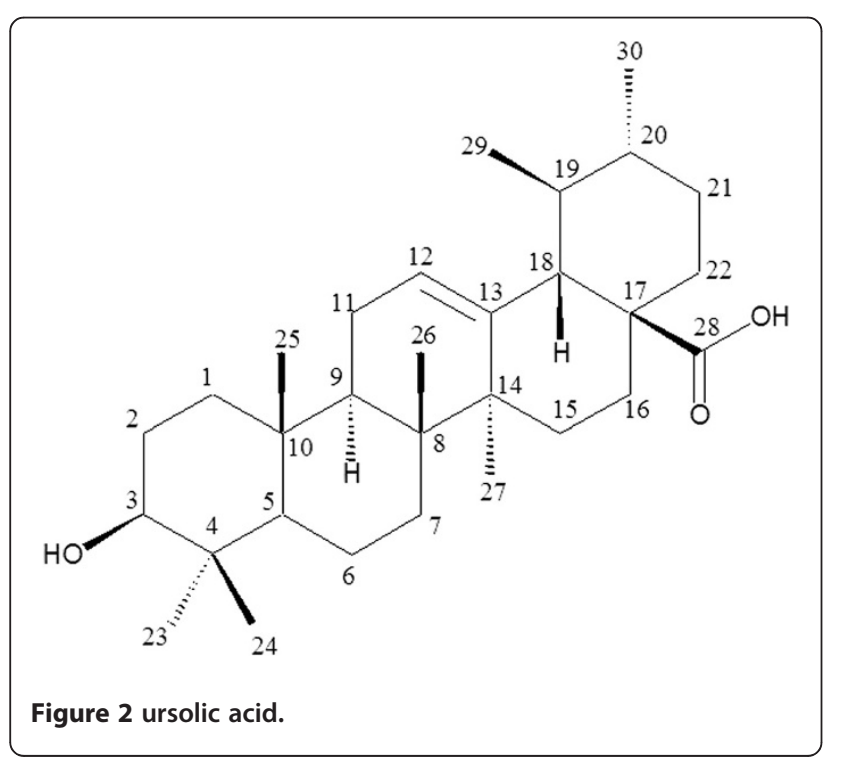

Table $2{ }^{1} \mathrm{H}$ and ${ }^{13} \mathrm{CNMR}$ spectral data for compound 2

\begin{tabular}{|c|c|c|c|}
\hline Position & ${ }^{13}$ C-NMR $\left(\delta_{C}\right)$ & ${ }^{1} \mathrm{H}$-NMR $\left(\delta_{\mathrm{H}}\right)$ & $J_{\mathrm{HH}}(\mathrm{Hz})$ \\
\hline 1 & 38.5 & 1.56 & $m$ \\
\hline 2 & 27.4 & 1.43 & $\mathrm{~m}$ \\
\hline 3 & 79.1 & 3.13 & $\mathrm{dd}, J=10.0,4.5$ \\
\hline 4 & 38.7 & - & - \\
\hline 5 & 52.4 & 0.66 & s \\
\hline 6 & 18.3 & 1.47 & $\mathrm{~m}$ \\
\hline 7 & 33.2 & 1.27 & $\mathrm{~m}$ \\
\hline 8 & 39.6 & - & - \\
\hline 9 & 47.4 & 1.58 & s \\
\hline 10 & 37.1 & - & - \\
\hline 11 & 23.9 & 1.92 & $\mathrm{dd}, J=13.7,3.5$ \\
\hline 12 & 125.8 & 5.20 & $\mathrm{t}, J=3.5$ \\
\hline 13 & 138.7 & - & - \\
\hline 14 & 42.0 & - & - \\
\hline 15 & 29.4 & 1.01 & $\mathrm{~m}$ \\
\hline 16 & 23.5 & 1.53 & $\mathrm{~m}$ \\
\hline 17 & 47.9 & - & - \\
\hline 18 & 55.2 & 2.20 & $\mathrm{~d}, J=11.3$ \\
\hline 19 & 30.5 & 1.31 & $\mathrm{~m}$ \\
\hline 20 & 30.3 & 1.52 & $\mathrm{~m}$ \\
\hline 21 & 27.5 & 1.29 & $\mathrm{~m}$ \\
\hline 22 & 37.0 & 1.54 & $\mathrm{~m}$ \\
\hline 23 & 24.0 & 1.11 & s \\
\hline 24 & 15.4 & 0.82 & s \\
\hline 25 & 15.9 & 0.97 & s \\
\hline 26 & 17.2 & 0.86 & s \\
\hline 27 & 24.5 & 1.20 & s \\
\hline 28 & 176.2 & - & - \\
\hline 29 & 22.4 & 0.79 & $\mathrm{~d}_{,} J=6.8$ \\
\hline 30 & 24.0 & 1.06 & $\mathrm{~d}, J=6.6$ \\
\hline
\end{tabular}

for inhibition of urease activity (Table 5). Table data revealed that (E)-N-(4-hydroxy-3-methoxyphenethyl)-3-(4-hydroxy3-methoxyphenyl) acryl amide (3) showed maximum inhibition might be responsible for antiulcer activity.

\section{Experimental}

\section{General}

Electron Impact Mass Spectra (EI-MS) were measured on Finnigan MAT-311 mass Spectrometer. High-Resolution Electron Impact Mass spectra (HREI-MS) were obtained on Jeol HX mass spectrometer. IR spectra were obtained in chloroform by using JASCO IRA-1 and JASCO A-302 spectrophotometers. $\mathrm{KBr}$ discs as supporting suface and $\mathrm{CHCl}_{3}$ was used as dissolving solvent. Ultraviolet (UV) spectra of UV active compounds were recorded in 


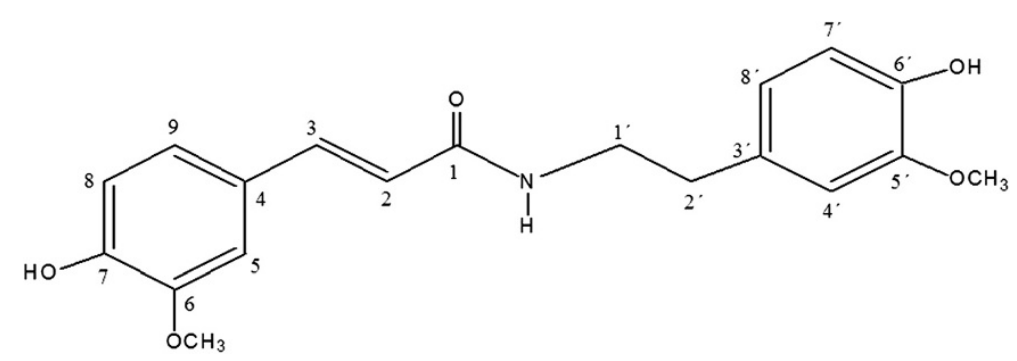

Figure 3 (E)-N-(4-hydroxy-3-methoxyphenethyl)-3-(4-hydroxy-3-ethoxyphenyl) acryl amide.

methanol by using a Shimadzu UV-240 and U-3200 Hitachi spectrophotometer. The ${ }^{1} \mathrm{H}$ and ${ }^{13} \mathrm{CNMR}$, COSY $45^{\circ}, \mathrm{HMQC}$ and $\mathrm{HMBC}$ spectra were recorded on Bruker AV-400 and AV-500 spectrometer.

\section{Plant materials}

The A. javanica (whole plant) was collected from Bannu Township, Bannu, Khyber Pakhtunkhwa in March 2010. The plant was identified by Professor Abdur Rehman, Department of Botany, Government Post Graduate College Bannu, Pakistan and a specimen (W-12) was submitted at Herbarium of Biotechnology and Botany

\section{Table 3 Prominent ${ }^{1} \mathrm{H}$ and ${ }^{13} \mathrm{CNMR}$ spectral data for} compound 3

\begin{tabular}{|c|c|c|c|}
\hline Position & ${ }^{13} \mathrm{C}-\mathrm{NMR}(\delta \mathrm{C})$ & ${ }^{1} \mathrm{H}-\mathrm{NMR}\left(\delta_{\mathrm{H}}\right)$ & $J_{\mathrm{HH}}(\mathrm{Hz})$ \\
\hline \multicolumn{4}{|c|}{ Feruloyl moiety } \\
\hline 1 & 169.2 & - & - \\
\hline 2 & 118.8 & 5.82 & $\mathrm{~d}, J=12.8$ \\
\hline 3 & 142.0 & 6.61 & $\mathrm{~d}, J=12.8$ \\
\hline 4 & 132.1 & - & - \\
\hline 5 & 111.6 & 7.36 & $\mathrm{~d}_{1} J=2.0$ \\
\hline 6 & 149.9 & - & - \\
\hline 7 & 149.0 & - & - \\
\hline 8 & 116.5 & 6.73 & $\mathrm{~d}_{1} J=8.4$ \\
\hline 9 & 123.2 & 6.93 & $\mathrm{dd}, J=8.4,2.0$ \\
\hline OMe & 56.4 & 3.82 & s \\
\hline \multicolumn{4}{|c|}{ Methoxytyramine moiety } \\
\hline $1^{\prime}$ & 42.5 & 3.49 & $\mathrm{t}, J=7.2$ \\
\hline $2^{\prime}$ & 36.2 & 2.77 & $\mathrm{t}, J=7.2$ \\
\hline $3^{\prime}$ & 128.3 & - & - \\
\hline $4^{\prime}$ & 113.5 & 6.82 & $\mathrm{~d}, J=2.0$ \\
\hline $5^{\prime}$ & 149.3 & - & - \\
\hline $6^{\prime}$ & 146.1 & - & - \\
\hline $7^{\prime}$ & 116.2 & 6.63 & $\mathrm{~d}, J=8.0$ \\
\hline $8^{\prime}$ & 122.3 & 6.67 & $\mathrm{dd}, J=8.0,2.0$ \\
\hline OMe' & 56.6 & 3.88 & s \\
\hline
\end{tabular}

University of Science and Technology Bannu KPK, Pakistan.

\section{Extraction and isolation}

The air-dried plant $(20 \mathrm{~kg}$ ) was chopped and was initially extracted with methanol/water (4:1) at room temperature. The hydromethanolic extract $(700 \mathrm{~g})$ was initially partitioned into $n$-hexane $(84 \mathrm{~g})$. The defatted $\mathrm{MeOH}$ extract was dried and then suspended in $\mathrm{H}_{2} \mathrm{O}$ (2 L), was successively partitioned with dichloromethane (110 g), and ethyl acetate (27 g). The EtOAc soluble fraction was subjected to $C C$ by using normal silica gel. The eluent used were n-hexane, EtOAc, DCM and $\mathrm{MeOH}$ in gradient manner to obtain compounds $\mathbf{1}-\mathbf{3}$.

\section{Compound 1}

White Powder; m.p $116-117^{\circ} \mathrm{C}$; IR $\left(\mathrm{KBr}, \mathrm{CHCl}_{3}\right) v_{\max }$ $\left(\mathrm{cm}^{-1}\right)$ : 3600-2500, 2685; ${ }^{1} \mathrm{H}$ and ${ }^{13} \mathrm{C}$ NMR spectral data, see Table 1; EI-MS $m / z$ (rel. int.): [M] ${ }^{+}, 152.0$ (100), 151 (94), 137 (5), 109 (24), 95 (3), 81 (27), 43(20); HR-EI-MS: $m / z[\mathrm{M}]^{+} 152.0$ (calcd for $\mathrm{C}_{8} \mathrm{H}_{8} \mathrm{O}_{3}, 152.05$ ).

\section{Compound 2}

White crystals; m.p $283-285^{\circ} \mathrm{C} ; \quad[\alpha]_{\mathrm{D}}^{20}+62.5^{\circ} \quad(\mathrm{c}=0.2$, $\left.\mathrm{CHCl}_{3}\right)$; IR $\left(\mathrm{KBr}, \mathrm{CHCl}_{3}\right) v_{\max }\left(\mathrm{cm}^{-1}\right): 3510,3050,1697$, 1635, 820; ${ }^{1} \mathrm{H}$ and ${ }^{13} \mathrm{C}$ NMR spectral data, see Table 2; EI-MS $m / z$ (rel. int.): $\left[\mathrm{M}^{+}, 456\left(\mathrm{M}^{+}, 10\right), 411\right.$ (22), 248 (34), 203 (100), 189 (16); HR-EI-MS: $m / z[\mathrm{M}]^{+} 456.3599$ (calcd for $\mathrm{C}_{30} \mathrm{H}_{48} \mathrm{O}_{3}, 456.3603$ ).

Table 4 Effects of various fractions on Urease inhibition

\begin{tabular}{lll}
\hline Sr.\# & Name of the fraction & \% Inhibition \\
\hline 1 & $0.2 \mathrm{mg} / \mathrm{ml}$ Hexane & $15.3 \pm 1.2^{\mathrm{a}}$ \\
2 & $0.2 \mathrm{mg} / \mathrm{ml}$ Dichloromethane & $33.4 \pm 3.2^{\mathrm{b}}$ \\
3 & $0.2 \mathrm{mg} / \mathrm{ml}$ Ethyl acetate & $54.6 \pm 4.1^{\mathrm{c}}$ \\
4 & $0.2 \mathrm{mg} / \mathrm{ml}$ Water & $5.1 \pm 0.9^{\mathrm{a}}$ \\
5 & $0.2 \mathrm{mg} / \mathrm{ml}$ Thiourea & $98.2 \pm 5.1^{\mathrm{d}}$ \\
\hline
\end{tabular}

Each value $(a, b, c$ and $d)$ in the table is represented as mean \pm SD $(n=3)$. 
Table 5 Effects of isolated compounds $1-3$ on Urease inhibition

\begin{tabular}{lll}
\hline Sr.\# & Name of the compounds & \% Inhibition \\
\hline 1 & $0.2 \mathrm{mg} / \mathrm{ml}$ Compound $\mathbf{1}$ & $15.3 \pm 0.8^{\mathrm{a}}$ \\
2 & $0.2 \mathrm{mg} / \mathrm{ml}$ Compound $\mathbf{2}$ & $33.4 \pm 2.7^{\mathrm{b}}$ \\
3 & $0.2 \mathrm{mg} / \mathrm{ml}$ Compound $\mathbf{3}$ & $64.6 \pm 4.2^{\mathrm{c}}$ \\
4 & $0.2 \mathrm{mg} / \mathrm{ml}$ Thiourea & $98.2 \pm 4.3^{\mathrm{d}}$ \\
\hline
\end{tabular}

Each value $(a, b, c$ and $d)$ in the table is represented as mean $\pm S D(n=3)$.

\section{Compound 3}

Yellowish white amorphous powder; m.p $111-113^{\circ} \mathrm{C}$, IR $\left(\mathrm{KBr}, \mathrm{CHCl}_{3}\right) v_{\max }\left(\mathrm{cm}^{-1}\right): 3440,3350,1680,1650 ;{ }^{1} \mathrm{H}$ and ${ }^{13} \mathrm{C}$ NMR spectral data, see Table 3; EI-MS $m / z$ (rel. int.): $[\mathrm{M}]^{+}, 343$ (20), 193 (30), 177 (94), 151 (25), 150 (100), 145 (30), 55 (6); HR-EI-MS: $m / z$ [M] 343.1411 (calcd for $\mathrm{C}_{19} \mathrm{H}_{21} \mathrm{NO}_{5}, 343.1420$ ).

\section{Urease enzyme inhibition assay}

Urease (Jack bean) solution $(25 \mu \mathrm{l})$ was mixed with the $5 \mathrm{mg}(500 \mu \mathrm{g})$ extracts and the mixture was incubated at $30^{\circ} \mathrm{C}$. Aliquot were taken after $15 \mathrm{~min}$ and then was transferred to assay mixtures having urea $(100 \mathrm{mM})$ in buffer $(40 \mu \mathrm{l})$ and again incubated for $30 \mathrm{~min}$ in 96 well plates. Urease activity was determined by measuring ammonia production using the indophenol method as described [18]. Briefly, $50 \mu 1$ each of phenol reagent $(1 \% \mathrm{w} / \mathrm{v}$ phenol and $0.005 \% \mathrm{w} / \mathrm{v}$ sodium nitroprusside) and $70 \mu 1$ of alkali reagent $(0.5 \% \mathrm{w} / \mathrm{v} \mathrm{NaOH}$ and $0.1 \%$ active chloride $\mathrm{NaOCI}$ ) were added to each well. The increasing absorbance was measured after $50 \mathrm{~min}$ at wavelength of $630 \mathrm{~nm}$ using microtitre plate reader (Spectramax plus 384 Molecular Device, USA). All reactions were performed in triplicates in final volume of $200 \mu \mathrm{l}$. All the assays were performed at $\mathrm{pH} 8.2(0.01 \mathrm{M}$ $\mathrm{K}_{2} \mathrm{HPO}_{4} \cdot 3 \mathrm{H}_{2} \mathrm{O}, 1 \mathrm{mM}$ EDTA and $0.01 \mathrm{M} \mathrm{LiC1}_{2}$ ). Thiourea was used as standard and percentage inhibitions were calculated from formula, 100 - (OD test/OD control) $\mathrm{x}$ 100. In this study, the reductive ability was measured by investigating the $\mathrm{Fe}^{+3} \rightarrow \mathrm{Fe}$ transformation in the presence of various extracts of plants and standard antioxidant (BHA) by using the Oyaizu method [19].

\section{Statistical analysis}

The parametric data were expressed as the mean \pm SEM for the 03 replicates in each group. To determine the differences between groups one-way analysis of variance (ANOVA) was carried out by using the SPSS software (version 13.0) using the least significant difference (LSD) test at $P<0.01$. Means not sharing the same letter are significantly different (LSD) at $P<0.01$ probability level in each column.

\section{Conclusion}

The current phytochemical study provided preliminary data for the first time that the A. javanica possesses significant anti-ulcer activity. This might be contributed towards the presence of some bioactive constituents contributed towards the various biological activities including the in the treatment of gastric ulcer. The compound 3 shows mild activity which might be due to the presence of amide group. Further study on the plant and specifically on the compound $\mathbf{3}$ could provide many chemically interesting and biologically active drugs, including, some with potential anti-ulcer properties.

\section{Competing interest}

The authors declare that they have no competing interests.

\section{Authors' contributions}

SJ has supervised all the research work carried out. AWK carried out isolation, purification and characterization of the constituents. SP and AAS facilitate in research work. RAK made a significant contribution to acquisition of data, analysis, drafting of the manuscript. AJT and AS helped in extraction. All authors read and approved the final manuscript.

\section{Acknowledgment}

Provision of research facility at the premier research center, the H.E.J. Research Institute of Chemistry, International Center for Chemical and Biological Sciences, University of Karachi, Karachi is highly acknowledged.

\section{Author details}

'Department of Chemistry, University of Science and Technology, Bannu 28100, Pakistan. ${ }^{2}$ Department of Biotechnology, University of Science and Technology, Bannu 28100, Pakistan. ${ }^{3}$ Department of Biological Sciences, Gomal University, D.I. Khan, Pakistan. ${ }^{4}$ College of Veterinary Sciences, Gomal University, D.I. Khan, Pakistan. ${ }^{5}$ Department of Agriculture Chemistry, KPK Agriculture University Peshawar, Peshawar, Pakistan.

Received: 19 June 2012 Accepted: 17 July 2012

Published: 31 July 2012

\section{References}

1. Alvarez-Suarez JM, Dekanski D, Risti S, Radonji NV, Petronijevi ND, Giampieri F, Astolfi P, González-Paramás AM, Santos-Buelga C, Tulipani S, Quiles JL, Mezzetti B, Battino M: Strawberry polyphenols attenuate ethanol-induced gastric lesions in rats by activation of antioxidant enzymes and attenuation of MDA increase. PLOS One 2011, 6(10):e25878.

2. Monforte MT, Lanuzza F, Pergolizzi S, Mondello F, Tzakou O, Galati EM: Protective effect of Calamintha officinalis Moench leaves against alcohol-induced gastric mucosa injury in rats. Macroscopic, histologic and phytochemical analysis. Phytother Res 2012, 26(6):839-44.

3. Burkill HM: The useful plants of West Tropical Africa, Families A-D. UK: Royal Botanic Gardens; 1985:446-447.

4. Emam SS: Phytochemical studies on the herb Aerva javanica growing in Egypt. Cairo University Faculty of Agriculture Bulletin 1999, 50:488-514.

5. Khan UG, Nazir T, Ahmed VU: Chemical Constituents of Aerva Javanica. Fitoterapia 1982, 53:75-77.

6. Deshmukh T, Yadav BV, Badole SL, Bodhankar SL, Dhaneshwar SR: Antihyperglycaemic activity of alcoholic extract of Aerva lanata (L.) A. L. Juss. Ex J. A. Schultes leaves in alloxan induced diabetic mice. J App Biomed 2008, 6:81-87.

7. Garg SP, Bhushan R, Kapoor RC: Aervanone, a new flavanone from Aerva persica. Phytochemistry 1980, 19:1265.

8. Singh R, Jain SC, Jain R: Antioxidant activity of some medicinally important arid zone plants. Asian J Exp Sci 2010, 23:215-221.

9. Baltina LA, Flekhter OB, Nigmatullina LR, Boreko El, Pavlova NI, Nikolaeva SN, Tolstikov GA: Lupane triterpenes and derivatives with antiviral activity. J Bioorganic Med Chem Lett 2003, 13:3549-3552. 
10. El-Hadi MA, Barki YMN, Yousif GM, Hassan SK: Antiplasmodial activity of some medicinal plants used in sudanese folk-medicine. Environ Health Insight 2010, 4:1-6.

11. Srinivas KR, Reddy VM: Antihyperglycaemic activity of ethanol extract of Aerva javanica leaves in alloxan- induced diabetic mice. J of Pharmacy Research 2009, 2:1259-1261.

12. Okwu DE: Flavouring properties of spices on cassava Fufu. Afric J Roots Tuber Crops 1999, 2:19-21.

13. Rama NH, Wadood A, Obaid OR, Baber TM, Ali Fl, Ahmed S, Haq Z, Khan RA, Choudhary MI: Synthesis of 1,4-diaryl-2-naphthoates based on siteselective Suzuki-Miyaura reactions. Med Chem Lett 2010, 1:145-149.

14. Spiro HM: Clinical Gastroenterology. Macmillan Pub. Newyork; 1977:292-304.

15. Kurata JH, Haile BM: Epidemiology of peptic ulcer disease. Clin Gastroenterol 1984, 13:289-307.

16. Pharmaguide, Handbook of all medicines in Pakistan. Karachi, Pakistan: Pharmaguide Publishing Company; 2006:25.

17. Sharif A, Ahmed E, Malik A, Hassan MU, Munawar MA, Farrukh A, Nagra SA, Anwar J, Ashraf M, Mahmood Z: Antimicrobial Constituents from Aerva javanica. J Chem Soc Pak 2011, 33:3.

18. Weatherburn MW: Phenol-hypochlorite reaction for determination of ammonia. Anal Chem 1967, 39:971-974.

19. Oyaizu M: Studies on products of browning reaction prepared from glucosamine. Jpn J Nutr 1986, 44:307-315.

doi:10.1186/1752-153X-6-76

Cite this article as: Khan et al:: Phytochemical analysis and Enzyme

Inhibition Assay of Aerva javanica for Ulcer. Chemistry Central Journal 2012 6:76.

\section{Publish with ChemistryCentral and every scientist can read your work free of charge \\ "Open access provides opportunities to our colleagues in other parts of the globe, by allowing anyone to view the content free of charge." \\ W. Jeffery Hurst, The Hershey Company. \\ - available free of charge to the entire scientific community \\ - peer reviewed and published immediately upon acceptance \\ - cited in PubMed and archived on PubMed Central \\ - yours - you keep the copyright \\ Submit your manuscript here: \\ http://www.chemistrycentral.com/manuscript/<smiles>c1ccccc1</smiles> \\ Chemistry Central}

